\title{
Herpes-like virus infection causing mortality of cultured abalone Haliotis diversicolor supertexta in Taiwan
}

\author{
Pen Heng Chang ${ }^{1, *}$, Shu Ting Kuo ${ }^{2}$, San Huei Lai ${ }^{1}$, Hong Shii Yang ${ }^{3}$, \\ Yun Yuan Ting ${ }^{3}$, Ching Lung $\mathrm{Hsu}^{4}$, Hon Cheng Chen ${ }^{5}$ \\ ${ }^{1}$ Department of Veterinary Medicine, College of Bio-Resources and Agriculture, National Taiwan University, Taipei 10617, \\ Taiwan, ROC \\ ${ }^{2}$ National Institute for Animal Health, Tansui 25158, Taiwan, ROC \\ ${ }^{3}$ Mariculture Research Center, Fisheries Research Institute, Tainan 72453, Taiwan, ROC \\ ${ }^{4}$ Department of Aquaculture and Coastal Fisheries, Council of Agriculture, Taipei 10093, Taiwan, ROC \\ ${ }^{5}$ Department of Zoology, College of Science, National Taiwan University, Taipei 10617, Taiwan, ROC
}

\begin{abstract}
A herpes-like virus is demonstrated for the first time to be associated with high mortality rates in maricultured abalone Haliotis diversicolor supertexta in Taiwan. Histopathology of moribund abalone indicated that the nerve system was the primary target tissue. The lesions were characterised by tissue necrosis accompanied with infiltration of haemocytes. Electron microscopic examination demonstrated viral particles within the degenerated cerebral ganglion cells. The viruses were hexagonal, approximately $100 \mathrm{~nm}$ in diameter and had a single coat. Some viral particles contained a dense nucleoid, while others were empty. The ultrastructure and morphogenesis of the virus particles were consistent with those of the herpesvirus described from the oyster Crassostrea virginica. Experimental infection using supernatant collected from minced visceral organs and muscle of moribund abalone induced $100 \%$ mortality through both intramuscular injection and bath treatments.
\end{abstract}

KEY WORDS: Herpes-like virus $\cdot$ Haliotis diversicolor supertexta $\cdot$ Mortality $\cdot$ Pathogenicity

\section{INTRODUCTION}

Herpes-like virus infection in marine bivalves was first observed in adult oysters Crassostrea virginica (Farley et al. 1972). Subsequently, this virus has been detected in other oyster species (Hine et al. 1992, Nicolas at al. 1992, Comps \& Cochennec 1993, Renault et al. 1994, 2000). Herpesviruses have also been characterised in nonostreid bivalves such as European clam Ruditapes decussatus and Manila clam R. philippinarum (Renault \& Arzul 2001, Renault et al. 2001). Among these viruses, ostreid herpesvirus-l (OsHV-1) (Minson et al. 2000) and a variant of OsHV-1 (OsHV-1 var) have been analysed by PCR (polymerase chain reaction), restriction endonuclease digestion of $\mathrm{PCR}$ products and DNA sequencing. OsHV-1 and OsHV-1 var are representatives of a single viral species that may be the ubiquitous cause of herpesvirus infections in marine bivalves (Arzul et al. 2001).

Abalones are members of the family Haliotidae and the genus Haliotis, having 1-piece shells. Mass mortality of the abalone associated with Vibrio carchariae and withering syndrome have been described (Gardner et al. 1995, Nicolas et al. 2002). The aetiological agent of withering syndrome has been identified as a unique taxon, and the provisional status of Candidatus xenohaliotis californiensis has been proposed (Friedman et al. 2000). However, the mortality of 
abalone caused by herpes-like viruses has not been reported.

The abalone Haliotis diversicolor supertexta is a dominant gastropod mollusc used for mariculture in Taiwan. Farms are located in coastal areas around the island. The annual product value of Taiwan abalone exceeds US\$200 million, including US\$58.8 million from those raised in farms along the northeast coast. In January 2003, high mortality of abalone occurred among both land-based and ocean-based ponds in north eastern Taiwan that resulted in losses of US\$11.5 million to the domestic abalone industry. We describe here for the first time a herpes-like virus that infects abalone cultured in Taiwan.

\section{MATERIALS AND METHODS}

Animals. Moribund abalone Haliotis spp., 5 to $6 \mathrm{~cm}$ in shell length, were collected from both land-based and ocean-based farms experiencing increasing mortality on the northeast coast of Taiwan in March 2003. Bacterial isolation was performed from the hepatopancreas, gonad and muscle by inoculating tissue onto Trypticase Soya agar (TSA, Difco) plates and incubating them at $30^{\circ} \mathrm{C}$ for $24 \mathrm{~h}$.

Histopathology. Samples of visceral organs, muscle and mantle were fixed in $10 \%$ neutral formalin, embedded in paraffin, sectioned at $5 \mu \mathrm{m}$ and stained with Mayer's haematoxylin and eosin ( $\mathrm{H} \& \mathrm{E}$ ).

Electron microscopy. Two different techniques were applied. For thin-section electron microscopy of paraffin-embedded tissues, cerebral ganglions were retrieved from the paraffin block, deparaffinised and reprocessed for electron microscopy. Then, $1 \mathrm{ml}$ of $2.5 \%$ glutaraldehyde (0.1 M cacodylate buffer, $\mathrm{pH} 7.2$ ) was added to the samples, and they were fixed for $6 h_{i}$ then they were rinsed and equilibrated 3 times for $10 \mathrm{~min}$ each using $0.1 \mathrm{M}$ cacodylate buffer. Osmium tetroxide (0.1 M cacodylate buffer, $\mathrm{pH} 7.2$ ) at $1 \%$ was carefully added to the samples, and they were kept at room temperature for $2 \mathrm{~h}$. Samples were rinsed and equilibrated 3 times for 10 min each using $0.1 \mathrm{M}$ cacodylate buffer, then dehydrated using a gradient series of ethanol at $35,50,70,85,90,95$ and $100 \%$, for 10 min each. Samples were immersed in a series of ethanol-resin mixtures for $2 \mathrm{~h}$ each. The ratio of ethanol to resin was changed from 3:1 to 1:1 to 1:3. Samples were embedded by $100 \%$ resin immersion. Then, samples were polymerised for $24 \mathrm{~h}$ at $70^{\circ} \mathrm{C}$. Thick sections were stained with $1 \%$ toluidine blue solution and observed under a light microscope to determine cell morphology. Ultrathin sections $(0.35 \mathrm{~mm})$ were double-stained with $1 \%$ uranyl acetate and lead citrate and examined using transmission electron microscopy.
For negative-contrast electron microscopy, samples of visceral organs, muscle and mantle of 10 moribund abalone were pooled, homogenised in phosphatebuffered saline (PBS) to give a $10 \%(\mathrm{w} / \mathrm{v})$ suspension, and centrifuged at $3000 \times g$ for $20 \mathrm{~min}$ at $4{ }^{\circ} \mathrm{C}$. The supernatant was centrifuged at $100000 \times g$ for $10 \mathrm{~min}_{i}$ the pellet was negatively stained with $2 \%$ phosphotungstic acid and examined using electron microscopy (Bozzola \& Russell 1992, Lipart \& Renault 2002).

Preparation of virus solution for the infection trail. Abalone collected from a farm was used for the study. Tissues were removed from moribund abalone, minced, resuspended in MEM and homogenised for 1 to 2 min in a Virtis blender. The homogenate was clarified by centrifugation at $1500 \times g$ for $20 \mathrm{~min}$ at $4^{\circ} \mathrm{C}$. The supernatant fluid was collected and passed through $0.45 \mathrm{~mm}$ membrane filters.

Infection trial. The susceptibility of abalone to herpes-like viruses was examined following experimental exposures with the viral supernatant. Three groups of 10 abalone each obtained from a farm in southern Taiwan that had not experienced an epizootic were divided into herpes-like-virus and control groups. Experiments were carried out in $100 \mathrm{l}$ glass aquaria containing $70 \mathrm{l}$ of salt water. Aquaria were aerated by water recirculating through in-tank, glass-wool filters at 17 to $20^{\circ} \mathrm{C}$. In the injection group, 10 abalone were intramuscularly (IM) injected with $0.1 \mathrm{ml}$ of supernatant. In the bath group, 10 abalone were bathed in a $500 \times$ diluted supernatant for $30 \mathrm{~min}$, and then stocked in separate aquaria. Two control groups were treated by both injection and bathing following the same procedures, but using MEM instead. Mortalities of abalone were recorded daily. Duplicate infection trials have been carried out in this study.

\section{RESULTS}

\section{Epidemiological investigation}

Commencing in January 2003, mass mortalities of Haliotis spp. occurred among cultured abalone in north eastern Taiwan. During the epizootic, the water temperature was 16 to $19^{\circ} \mathrm{C}$. Both adult and juvenile abalone suffered from the disease, with cumulative mortalities of 70 to $80 \%$. Death of all of the abalone in a pond can occur within $3 \mathrm{~d}$ of the onset of clinical signs. The disease was reported only in $H$. diversicolor supertexta, while cohabitating Japanese black abalone $H$. discus remained normal. The gross appearance of affected abalone revealed mantle recession and muscle stiffness. 


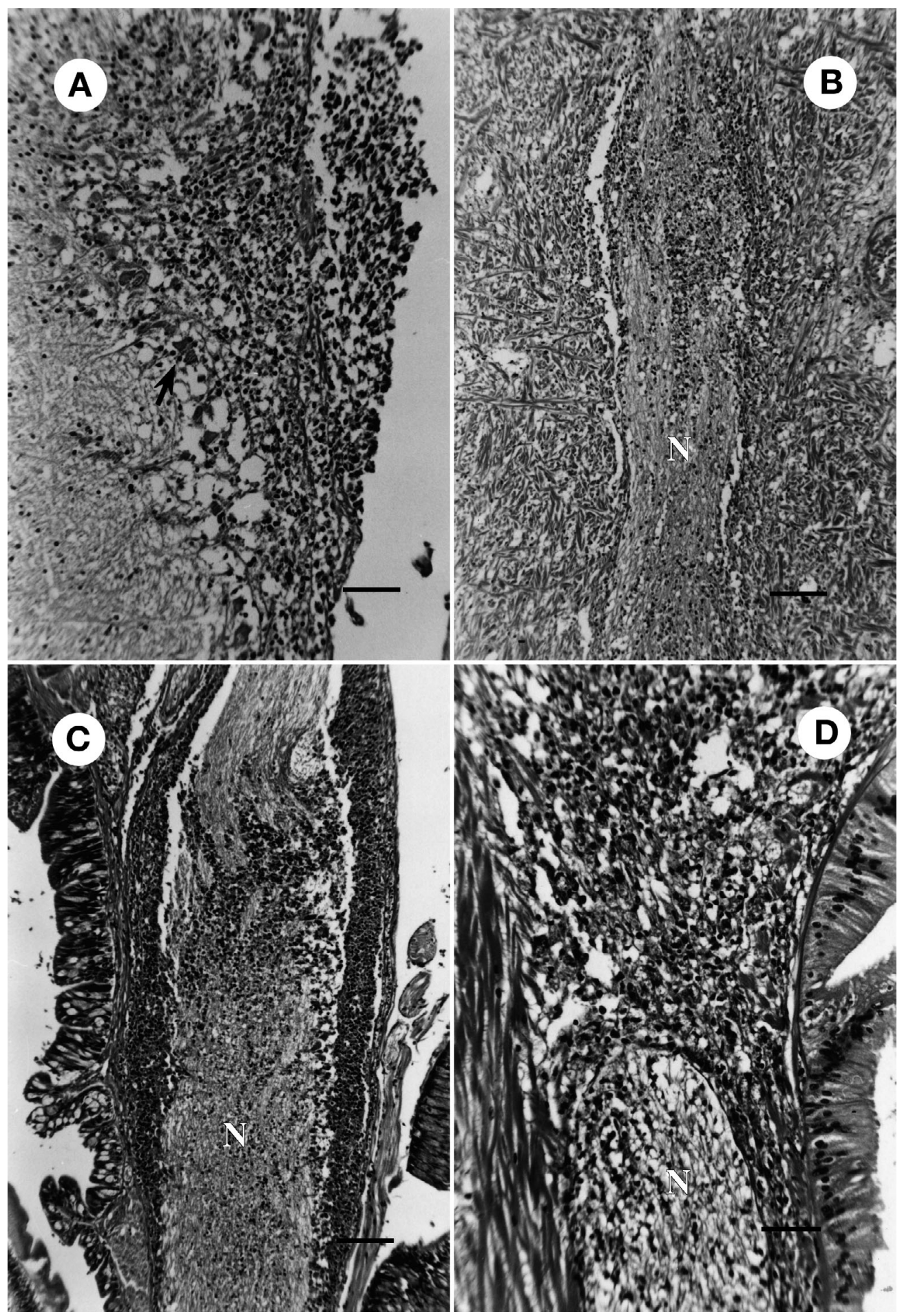

Fig. 1. Haliotis diversicolor supertexta. (A) Histological examination of the cerebral ganglion revealing lesions in the cerebral ganglion and surrounding neurilemma. Diffuse necrosis accompanied with infiltration of haemocytes was prominent in the tissue. Degenerated neurosecretory cells (arrow) were noted. Scale bar $=50 \mu \mathrm{m}$. (B) Histological examination of the foot revealed lesions in the nerve $(\mathrm{N})$ and surrounding muscular tissue. Diffuse necrosis accompanied with infiltration of haemocytes was evident. Scale bar $=100 \mu \mathrm{m}$. (C) Histological examination of the oesophagus revealed lesions in the nerve (N) beneath the mucosa. The lesions involved the nerve and surrounding neurilemma. Scale bar $=100 \mu \mathrm{m}$. (D) Histological examination of the intestine revealed lesions in the muscle and adjacent nerve tissue $(\mathrm{N})$ beneath the mucosa. The lesions consisted of diffuse necrosis accompanied with infiltration of haemocytes. Scale bar $=50 \mu \mathrm{m}$ 


\section{Histopathology}

Histological examination of moribund abalone indicated that the nerve system was the primary target tissue. The lesions were characterised by tissue necrosis accompanied with infiltration of haemocytes. Lesions in the cerebral ganglion consisted of diffuse necrosis and prominent infiltration of haemocytes in the parenchyma and surrounding neurilemma (Fig. 1A). Lesions involving nerve tissues and the surrounding muscular tissue in the foot were evident (Fig. 1B). Similar lesions were also noted in the oesophagus (Fig. 1C) and intestine (Fig. 1D). In some cases, diffuse necrosis accompanied with infiltration of haemocytes in the epithelia and underlying lamina propria of branchial filaments was evident. The sloughing off epithelia were deposited in the interlamellar spaces.

\section{Electron microscopy}

TEM examination of cerebral ganglions demonstrated viral particles within the degenerated cells (Fig. 2A). The viral particles were hexagonal, 90 to $100 \mathrm{~nm}$ in diameter and had a single coat. Some particles contained a dense nucleoid, while others were empty (Fig. 2B). The morphology and size of the viral particles were most consistent with a herpes-type virus described from the oyster Crassostrea virginica (Farley et al. 1972). Negative-contrast electron microscope examination demonstrated viral particles in the pooled tissue. The viral particles were hexagonal, 90 to $100 \mathrm{~nm}$ in diameter and had a single coat.

\section{Infection trial}

Abalone died at 2 dpi (days post-inoculation) and $3 \mathrm{dpi}$ in the bath treatment, while all abalone died at 2 dpi with the IM-injection treatment. No abalone died in the control groups. Experimentally infected abalone in both IM-injection and bath groups developed lesions similar to those of naturally affected abalone. No macroscopic or microscopic lesions were observed in the 2 noninfected controls. A duplicate infection trail induced similar mortality and pathology in both treatments.

\section{DISCUSSION}

Herpes-like virus infections in abalone have not previously been reported. We now describe for the first time a herpes-like virus infection of maricultured

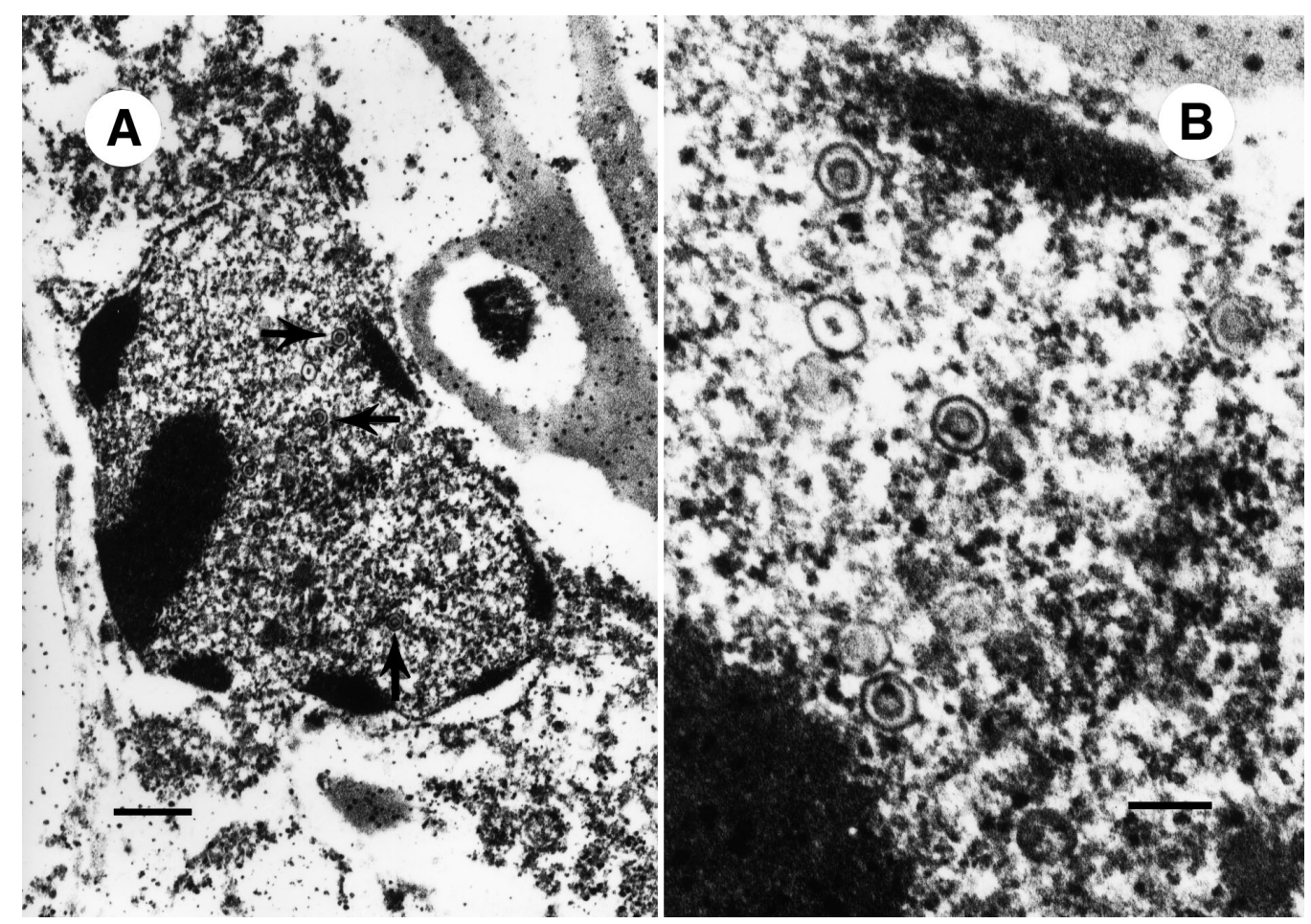

Fig. 2. Haliotis diversicolor supertexta. (A) TEM examination of cerebral ganglions showing viral particles (arrows) within degenerated cells. Scale bar $=416 \mu \mathrm{m}$. (B) The viral particles were hexagonal, 90 to $100 \mathrm{~nm}$ in diameter and had a single coat. Scale bar $=125 \mu \mathrm{m}$ 
abalone Haliotis diversicolor supertexta in association with high mortality rates. As the pathology specific to herpes-like virus infection has not been described and no abalone cell line is available to facilitate virus culture, infections were confirmed by detection of virus particles in the lesions and by infection trail.

The herpes-like virus detected in moribund abalone is a cytocidal virus, with necrosis as its principal pathological effect. The virus caused fatal disease, and exhibited a high degree of neurotropism. Nervous system involvement, affecting the cerebral ganglion and nerve bundles in the muscle of the foot as well as the muscular layers beneath the visceral organ, was noted, although it also induced lesions in other tissues.

Virus replication associated with tissue necrosis in the cerebral ganglion was demonstrated by TEM examination of paraffin-embedded tissues. The morphology and size of the virus particles were similar to those documented previously in the oyster (Farley et al. 1972, Roizman \& Baines 1991). The morphological form corresponding to replicating viruses was noted at an intranuclear location. Two classes of nucleocapsids were observed: one with an electron-dense core, which corresponds to DNA-containing capsids, and the other, which lacked the core. Enveloped capsids (virions) were not observed in the cytoplasm, due to destruction of cellular organisms by fixation.

The infection trail following IM-injection and bath treatments demonstrated the high degree of virulence by inducing $100 \%$ mortality in abalone. These results demonstrate that the virus induced mortalities and could be transmitted horizontally from infected to healthy abalone using the bath treatment. A pathology similar to that of the field cases was reproduced in the infection trail, and further confirms the tropism of herpes-like viruses for nerve tissues.

The focal origin, high mortality rates and lack of previous events of comparable magnitude suggest that the disease agent was probably an exotic pathogen. It is speculated that this virus was introduced through the importation of juvenile abalone, because a farmer had introduced juvenile abalone from abroad prior to this epizootic. During the epizootic, the highest prevalence was observed during the winter months. The prevalence dropped in the spring and summer periods, possibly because heavily infected individuals died in the winter, and the disease did not begin another cycle of increasing infection until autumn.

Editorial responsibility: Jo-Ann Leong, Kaneohe, Hawaii, USA
Acknowledgements. This study was supported by a grant from the Council of Agriculture, ROC.

\section{LITERATURE CITED}

Arzul I, Renault T, Lipart C, Davison AJ (2001) Evidence for interspecies transmission of oyster herpesvirus in marine bivalves. J Gen Virol 82:865-870

Bozzola JJ, Russell LD (1992) Electron microscopy: principles and techniques for biologists. Jones \& Bartlett, Boston, MA, p 108-182

Comps M, Cochennec N (1993) A herpes-like virus from the European oyster, Ostrea edulis L. J Invertebr Pathol 62: 201-203

Farley CA, Banfield WG, Kasnic JRG, Foster WS (1972) Oyster herpes-type virus. Science 178:759-760

Friedman CS, Andree KB, Beauchamp KA, Moore JD, Robbins TT, Shields JD, Hedrick RP (2000) 'Candidatus xenohaliotis californiensis', a newly described pathogen of abalone, Haliotis spp., along the west coast of North America. Int J Syst Evol Microbiol 50:847-855

Gardner GR, Harshbarger JC, Lake JL, Sawyer TK, Price KL, Stephenson MD, Haaker PL, Togstad HA (1995) Association of prokaryotes with symptomatic appearance of withering syndrome in black abalone, Haliotis cracherodii. J Invertebr Pathol 66:111-120

Hine PM, Wesney B, Hay BE (1992) Herpesvirus associated with mortalities among hatchery-reared larval Pacific oysters, C. gigas. Dis Aquat Org 12:135-142

Lipart C, Renault T (2002) Herpes-like virus detection in infected Crassostrea gigas spat using DIG-labelled probes. J Virol Meth 101:1-10

Minson AC, Davison A, Eberle R, Desrosiers RC and 5 others (2000) Family Herpesviridae. In: van Regenmortel MHV (ed) Virus taxonomy: 7th report of the international committee on taxonomy of viruses. Academic Press, San Diego, p 203-225

Nicolas JL, Comps M, Cochennec N (1992) Herpes-like virus infecting Pacific oyster larvae, C. gigas. Bull Eur Assoc Fish Pathol 12:11-13

Nicolas JL, Basuyaux O, Mazurie J, Thebault A (2002) Vibrio carchariae, a pathogen of the abalone Haliotis tuberculata. Dis Aquat Org 50:35-43

Renault T, Arzul I (2001) Herpes-like virus infections in hatchery-reared bivalve larvae in Europe: specific viral DNA detection by PCR. J Fish Dis 24:161-167

Renault T, Cochennec N, Le Deuff RM, Chollet B (1994) Herpes-like virus infecting Japanese oyster, C. gigas spat. Bull Eur Assoc Fish Pathol 14:64-66

Renault T, Le Deuff RM, Lipart C, Delsert C (2000) Development of a PCR procedure for the detection of a herpes-like virus infecting oysters in France. J Virol Meth 88:41-50

Renault T, Lipart C, Arzul I (2001) A herpes-like virus infects a non-ostreid bivalve species: virus replication in Ruditapes philippinarum larvae. Dis Aquat Org 45:1-7

Roizman B, Baines J (1991) The diversity and unity of Herpesviridae. Comp Immunol Microbiol Infect Dis 14:63-79

Submitted: February 18, 2004; Accepted: December 23, 2004

Proofs received from author(s): May 24, 2005 